\title{
Nickel Laterites-Mineralogical Monitoring for Grade Definition and Process Optimization
}

\author{
Uwe König
}

Citation: König, U. Nickel

Laterites-Mineralogical Monitoring for Grade Definition and Process Optimization. Minerals 2021, 11, 1178 https://doi.org/10.3390/ $\min 11111178$

Academic Editor: Fang Xia

Received: 21 September 2021

Accepted: 21 October 2021

Published: 24 October 2021

Publisher's Note: MDPI stays neutral with regard to jurisdictional claims in published maps and institutional affiliations.

Copyright: (C) 2021 by the author. Licensee MDPI, Basel, Switzerland. This article is an open access article distributed under the terms and conditions of the Creative Commons Attribution (CC BY) license (https:// creativecommons.org/licenses/by/ $4.0 /)$.
Malvern Panalytical B.V., Lelyweg 1, 7602 EA Almelo, The Netherlands; uwe.koenig@malvernpanalytical.com

\begin{abstract}
Nickel laterite ore is used to produce nickel metal, predominantly to manufacture stainless steel as well as nickel sulfate, a key ingredient in the batteries that drive electric vehicles. Nickel laterite production is on the rise and surpassing conventional sulfide deposits. The efficiency of mining and processing nickel laterites is defined by their mineralogical composition. Typical profiles of nickel laterites are divided into a saprolite and a laterite horizon. Nickel is mainly concentrated and hosted in a variety of secondary oxides, hydrous $\mathrm{Mg}$ silicates and clay minerals like smectite or lizardite in the saprolite horizon, whereas the laterite horizon can host cobalt that could be extracted as a side product. For this case study, 40 samples from both saprolite and laterite horizons were investigated using X-ray diffraction (XRD) in combination with statistical methods such as cluster analysis. Besides the identification of the different mineral phases, the quantitative composition of the samples was also determined with the Rietveld method. Data clustering of the samples was tested and allows a fast and easy separation of the different lithologies and ore grades. Mineralogy also plays a key role during further processing of nickel laterites to nickel metal. XRD was used to monitor the mineralogy of calcine, matte and slag. The value of mineralogical monitoring for grade definition, ore sorting, and processing is explained in the paper.
\end{abstract}

Keywords: nickel laterite; ore sorting; XRD; Rietveld; cluster analysis

\section{Introduction}

Battery manufacturing together with the demand for stainless steel is the biggest driver for the global nickel mining industry. About $60 \%$ to $70 \%$ of the current worldwide nickel resources are derived from laterites whereas the rest is extracted from nickel sulfide ores [1,2]. However, nickel laterites account currently only for about $40 \%$ of the global nickel production. Since ore grades and resources of sulfide nickel deposits generally decrease, mining companies are forced to focus more on the extraction of nickel from laterites in the future, see Figure 1.

Primary nickel production is generally divided into two main product categories. Nickel class I (nickel content $>99 \%$ ) describes a group of nickel products comprising electrolytic nickel, powders, and briquettes, as well as carbonyl nickel. Nickel class II (nickel content $<99 \%$ ) comprises nickel pig iron and ferronickel. These nickel products are used especially in stainless steel production. Roughly $48 \%$ of the total nickel mining output is related to class I nickel products, with class II nickel products accounting for the remaining $52 \%$ [3]. While class II nickel is mainly obtained from laterites, the production of class I nickel is based primarily on sulfide ores but moving to laterites too. Battery production requires class I nickel. Currently, approximately 5\% of the world nickel production is used to manufacture batteries. The high demand for electric vehicles together with increasing the energy density of the batteries forces manufacturers more and more to increase the nickel content and to decrease the cobalt content in batteries. In 2025 the demand for nickel for batteries is expected to increase by approximately $15 \%$ of the world nickel production [3]. The additional nickel supply will be mined mainly from lateritic deposits. 


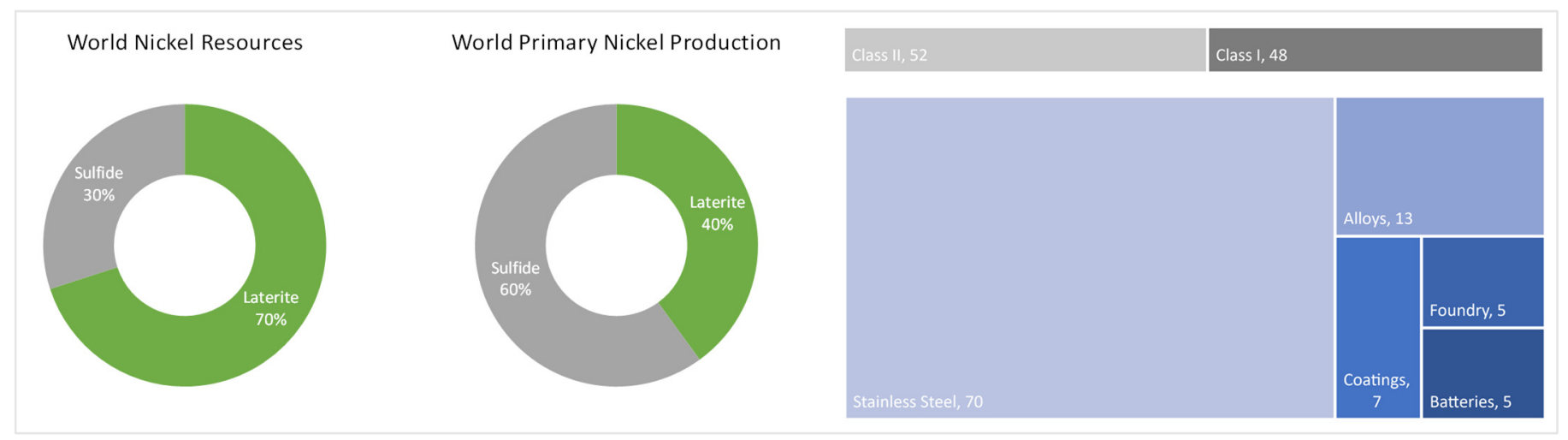

Figure 1. World nickel resources, production, and use (\%).

To extract nickel from laterites hydrometallurgical [4] and pyrometallurgical [5-7] processes are used. Whereas high-grade nickel laterites $(>2 \% \mathrm{Ni})$ are mainly processed pyrometallurgically, lower-grade nickel deposits $(<1.3 \% \mathrm{Ni})$ are processed mainly hydrometallurgically.

Nickel laterites form under humid tropical conditions during the weathering of serpentinite rocks. The mineralogy and ore grade depend on the lithology and climate during the formation of the deposit. Nickel is hosted in several minerals such as oxides, $\mathrm{Mg}$ silicates and clays. Laterite-type resources are found in Indonesia, the Philippines, Brazil, Cuba, Australia and New Caledonia. Lateritic nickel deposits can be classified in mainly three groups [8,9]: (a) oxidic or "limonitic" deposits dominated by minerals such as goethite FeOOH, (b) smectitic or "clay mineral" deposits dominated by nickel-bearing swelling clays such as smectite or nontronite and (c) hydrous Mg-Si-silicate deposits dominated by talc- and serpentine-like minerals, collectively referred to as "garnierites" [10,11] that occur in the saprolite zone of the yellow laterite profile, Figure 2.

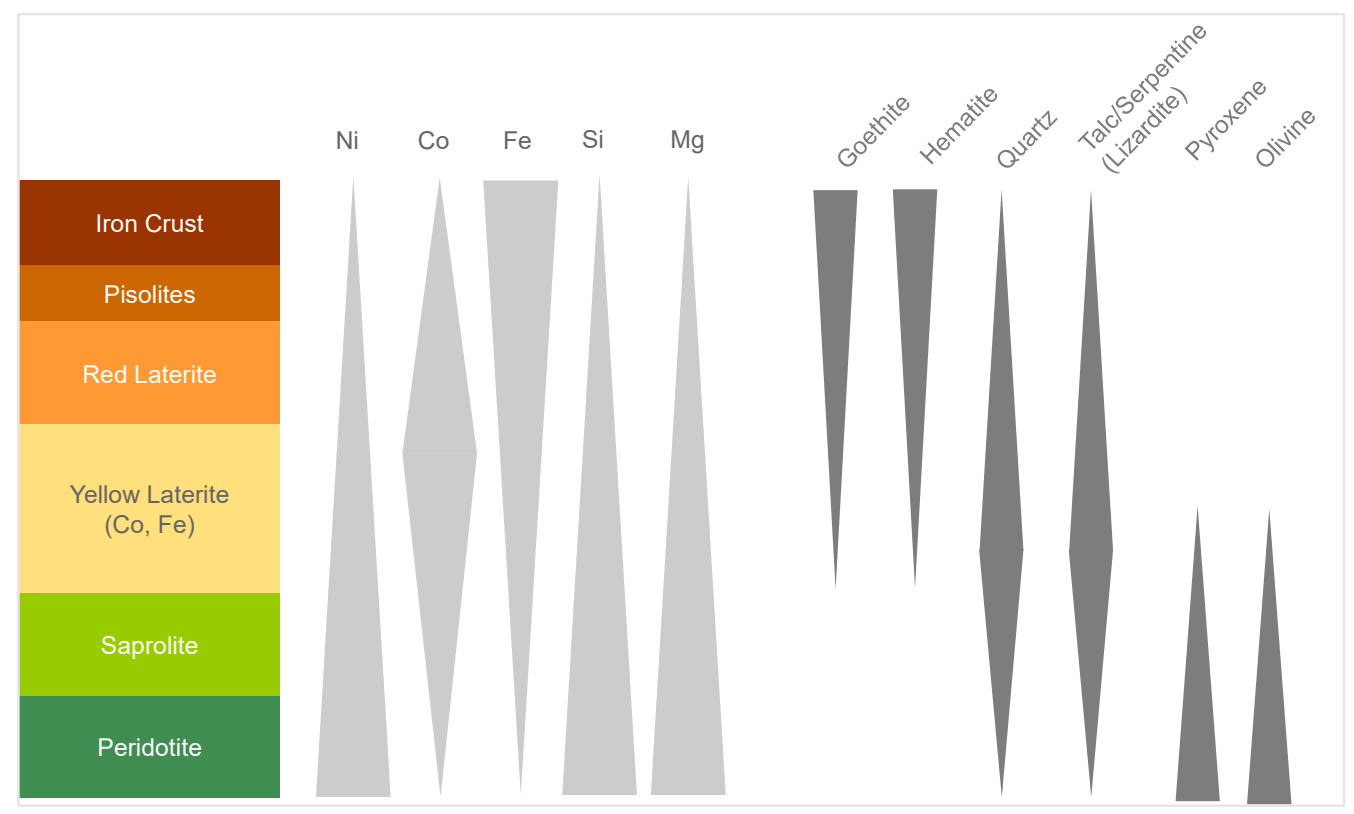

Figure 2. Schematic hydrous Mg-Si-silicate laterite profile modified after [12,13].

Garnierite is a general name defining greenish, poorly crystallized, clay-like Ni ores that generally comprises an intimate mixture of $\mathrm{Ni} / \mathrm{Mg}$ hydrosilicates like serpentine, lizardite, talc, sepiolite, smectite, and chlorite [10].

Currently, ore grades are mainly defined based on the elemental composition. Mineralogical analysis is only used for research on dedicated samples during mining and processing of nickel laterites or for the exploration of new deposits. This paper provides 
an overview of the value of mineralogical monitoring of lateritic nickel ores to increase the efficiency and the metal recovery during mining, ore sorting and blending as well as during pyrometallurgical processing.

\section{Materials and Methods}

\subsection{Samples and Sample Preparation}

40 nickel laterite samples from New Caledonia plus 6 samples from processed laterites were analyzed for this case study. The 40 samples are from both laterite and saprolite horizons of the nickel laterite profile, Figure 3. To guarantee a reproducible and constant sample preparation for the XRD measurements, the samples were prepared as pressed pellets using automated sample preparation equipment. All powder samples were milled for $30 \mathrm{~s}$ and pressed $30 \mathrm{~s}$ with 10 tons into steel ring sample holders. No binder was used to prepare the samples.

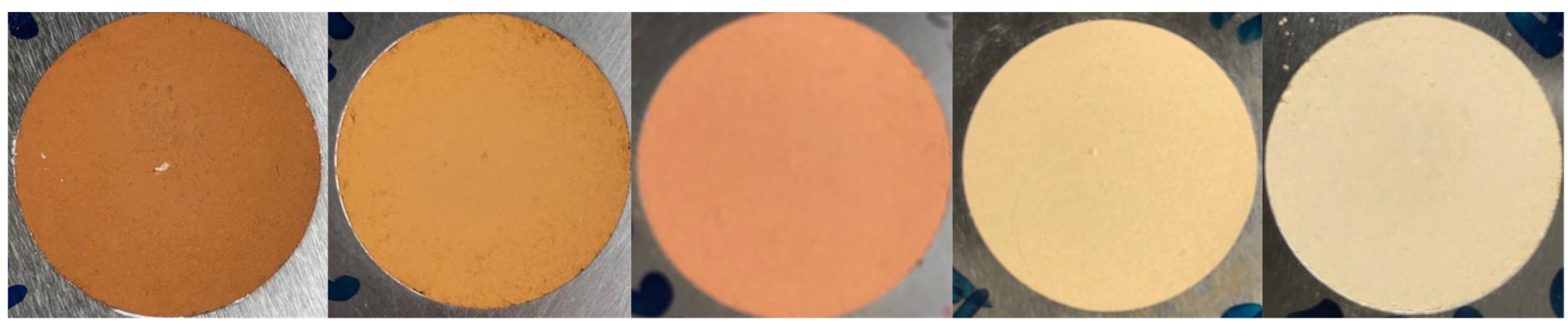

Figure 3. Selected nickel laterite samples prepared for XRD measurements representing five main groups in the nickel laterite profile, left $=$ high goethite, right $=$ high lizardite.

\section{2. $X$-ray Diffraction $(X R D)$}

$X$-ray powder diffraction (XRD) is a versatile, non-destructive analytical method for the identification and quantitative determination of crystalline phases present in powdered and bulk samples. For the studies presented in this paper, a Malvern Panalytical "Aeris Minerals" benchtop diffractometer (Almelo, The Netherlands) with a cobalt anode, an incident iron filter and a linear detector was used, featuring measurement times of about 5 min per sample. The XRD patterns were collected in the range $5^{\circ}$ to $82^{\circ} 2 \theta$. The setup consists of an X-ray source, a spinning sample stage for optimizing counting statistics, a high-speed detector, and several optics.

Data evaluation was performed with the software package HighScore Plus version 4.9 [14]. The identification of all crystalline mineral phases is achieved by comparing measured diffraction data to a reference database. For this study, the Crystallography Open Database (COD) from 2021 was used [15].

\subsection{Rietveld Quantification}

The mineral quantification of all samples was determined using the Rietveld method [16-18]. Modern XRD quantification analysis techniques such as Rietveld analysis are attractive alternatives to classical peak intensity or area-based methods since they do not require any standards or monitors. The method offers impressive accuracy and speed of analysis. The knowledge of the exact crystal structure of all minerals present in the nickel laterite samples is mandatory for the Rietveld refinements.

\subsection{Cluster Analysis}

To handle large amounts of data achieved by rapid data collection using a linear detector, "cluster analysis" is a useful tool to combine different XRD measurements (and thus different ore grades) into similar groups (clusters) $[19,20]$. The method can be used for stockpiling different grades of the nickel laterite profile with different mineralogical properties and thus varying process behavior. Cluster analysis can be also used to automatically 
apply dedicated Rietveld runs on different groups of samples with different mineralogical contents, to improve the accuracy of the quantitative results.

Cluster analysis greatly simplifies the analysis of large amounts of data. It automatically sorts all (closely related) scans of an experiment into separate groups and marks the most representative scan of each group as well as the most outlying scans within each group. Cluster analysis is basically a three-step process, but it contains optional visualization and verifications steps as well:

1. Comparison of all scans in a document with each other, resulting in a correlation matrix representing the dissimilarities of all data points of any given pair of scans.

2. Agglomerative hierarchical cluster analysis puts the scans in different classes defined by their similarity. The output of this step is displayed as a dendrogram, where each scan starts at the left side as an individual cluster. The clusters amalgamate in a stepwise fashion until they are all united in one single group.

3. The best possible grouping (=number of separate clusters) is estimated by the KGS test [19] or by the largest relative step on the dissimilarity scale. This number can be adapted manually too. Additionally, the most representative scan and the two most outlying scans within each cluster is determined and marked.

4. Next to hierarchical clustering you can use three independent tools, namely Principal Components Analysis (PCA), Metric Multi-Dimensional Scaling (MMDS), or t-Stochastic Neighbor Embedding (t-SNE) to define clusters; they are all shown in pseudo-three-dimensional plots.

t-SNE [21], as used in this case study, is a separate and independent method to visualize and to judge the quality of the clustering. Either the correlation matrix of step 1 , or the raw data is used as input, the output is again a pseudo-3-dimensional plot.

\subsection{Fuzzy Clustering}

Cluster analysis is not only a data reduction tool; it can also be used to discover hidden patterns in data as well as expose phase relationships in large numbers of patterns of complex mixtures. In order to be able to deal with phase mixtures without prior knowledge of the possible constituents, fuzzy clustering can be applied to the samples [22,23]. This cluster validation technique allows a member to join more than one cluster. It is sometimes called soft clustering too. For each member the probability (between one and zero) to join every cluster is calculated. The results are shown in a table.

- Probabilities $<0.2$ indicate members, which surely do not belong to this cluster.

- Probabilities $>0.7$ indicate members, which certainly do belong to a specific cluster.

- Probabilities between 0.2 and 0.7 indicate members, which could belong to more than one cluster. These should be inspected in more detail.

\subsection{X-ray Fluorescence (XRF)}

Elemental analysis was determined using $X$-ray fluorescence (XRF) technology. The powder samples were first dried in an oven at $105^{\circ} \mathrm{C}$ overnight. The mixture with $12 \mathrm{~g}$ dried sample material plus $3 \mathrm{~g}$ binder was ground with tungsten carbide swing mill for $30 \mathrm{~s}$. The mixture was then pressed into a $40 \mathrm{~mm}$ diameter pellet under 20 tons for $30 \mathrm{~s}$. A Malvern Panalytical "Epsilon 4" bench-top spectrometer (Almelo, The Netherlands) with $\mathrm{Rh}$ tube was used with measurement times of about 3 min per sample. Secondary Ni ore standards from New Caledonia were used to setup the calibration.

\section{Results and Discussion}

Evaluation of the XRD measurements was done in several steps. As a first step data clustering was applied to define mineralogical domains within the laterite horizon. A second step included minerals identification and quantification, and the results were compared to a typical nickel laterite horizon. Finally, the XRD results were validated with the elemental composition determined by XRF. 
In addition to the lateritic raw material 6 processed samples were analyzed to identify and quantify the phase composition.

\subsection{Cluster Analysis of Nickel Laterite}

All 40 samples of the lateritic profile were used for cluster analysis to define groups of similar mineralogical composition. Based on the correlation matrix the dendrogram in Figure 4 defines 4 cluster plus 3 outliers. The different cluster are visualized in a 3-dimensional t-SNE plot, Figure 5.

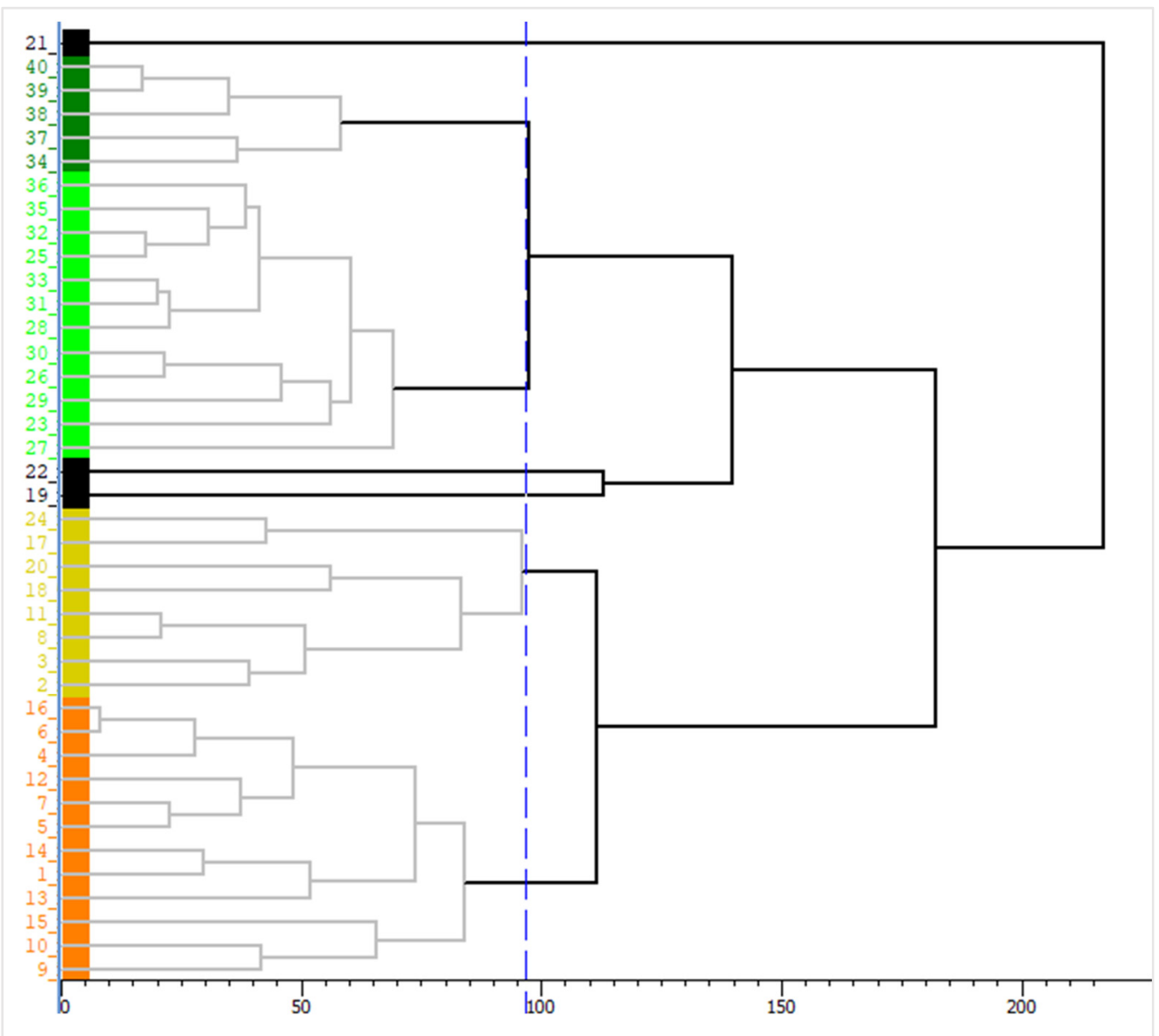

Figure 4. Dendrogram after cluster analysis based on the correlation matrix from 40 nickel laterite samples (cluster 1 = orange, cluster 2 = yellow, cluster $3=$ light green, cluster $4=$ dark green), $\mathrm{X}$-axis shows the dissimilarity of the tie bars.

Phase identification and quantification, Section 3.2, confirmed that the 4 cluster represent different parts of the laterite horizon. Cluster 1 represents samples from the laterite horizon with high content of goethite whereas cluster 2 contains laterite samples with high quartz content. Clusters 3 and 4 consist of saprolite samples with high lizardite content in cluster 3 and high olivine and pyroxene content in cluster 4.

The outliers are samples with very low goethite content $(<10 \%$, samples $19,21,22)$ and with a far higher amount of gibbsite (sample 19) compared to the other samples. 


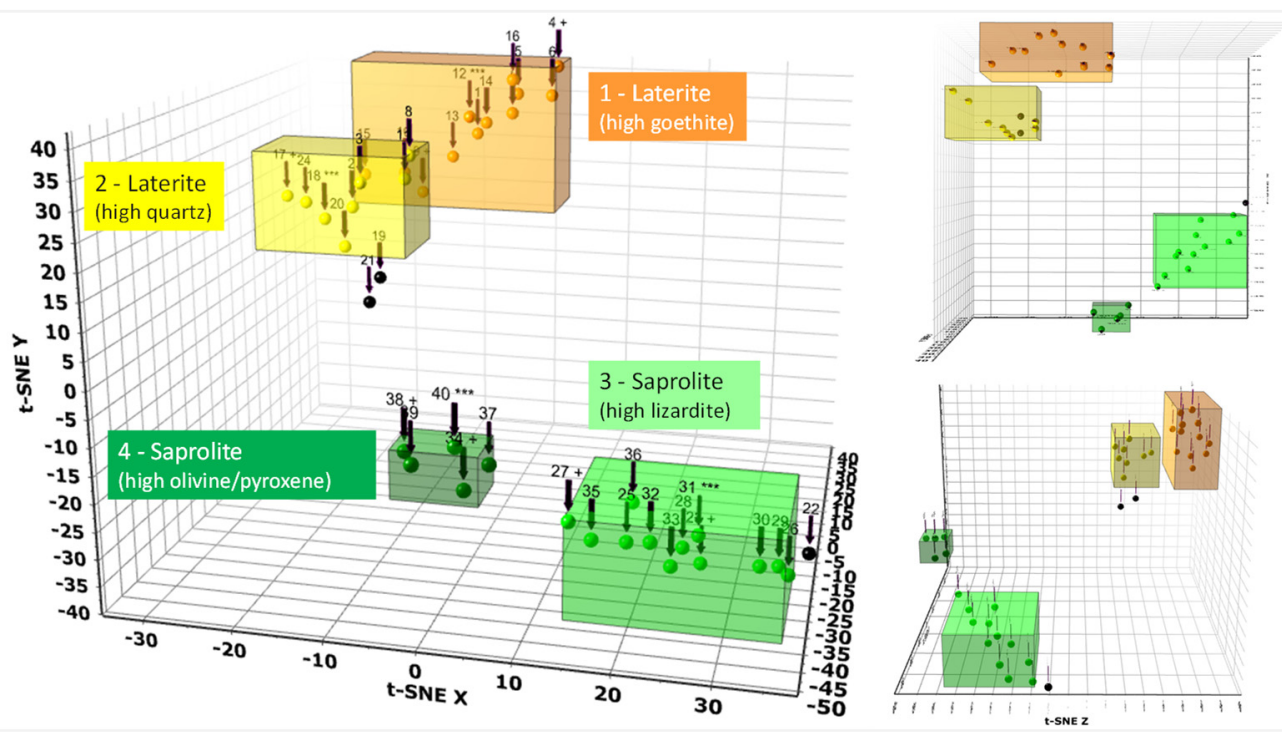

Figure 5. 3D t-SNE score plot after data clustering of 40 samples, visuals from 3 different angles.

To explore the possible transitions between the different mineralogical horizons (in contrast to sharp borders) fuzzy clustering was applied. The fuzzified 3D t-SNE score plot, Figure 6, clearly points towards such transitions. Mixed colors mark the scans that belong to transitions and larger spheres indicate those scans where the membership coefficient exceeds/falls under a certain threshold.

The results in Table 1 show the matrix notation, the so-called membership matrix $M$, with all calculated probabilities for each measurement. Clusters are organized in columns, probabilities for each sample are shown in a row.
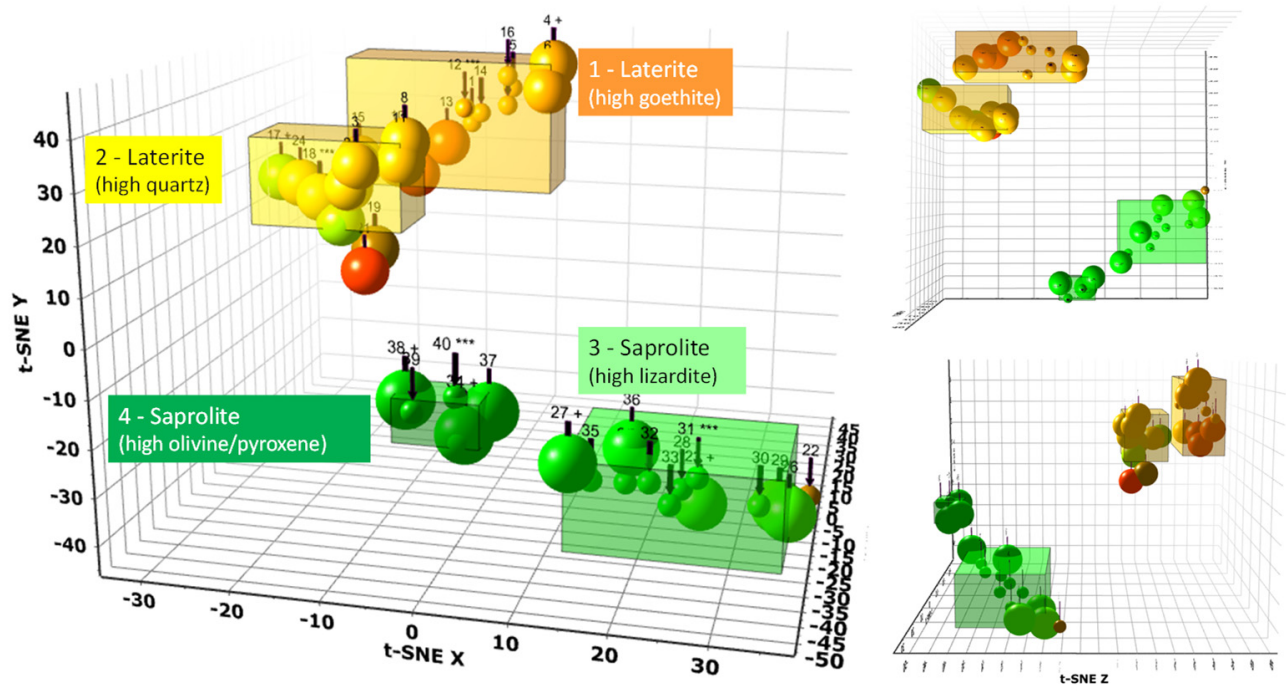

Figure 6. Fuzzified 3D t-SNE score plot, phase mixtures are indicated by mixed colors and larger spheres.

The results prove the capability of fuzzy clustering to detect transitions as mixtures of adjacent clusters. Figure 7 shows the 4 cluster and the membership coefficients. The trendlines indicate high membership and better separation for clusters 1, 3 and 5. Cluster 2 with lower coefficients is made up by mixing mineral associations from cluster one and three and represents transition mineralogy. 
Table 1. Results of fuzzy clustering of 40 nickel laterite samples, refined membership coefficients, colors represent the different cluster as identified in Figures 5 and 6, Liz = Lizardite, Oli = Olivine, Ens = Enstatite.

\begin{tabular}{|c|c|c|c|c|c|c|}
\hline Cluster No. & Sample No. & Laterite & Transition & $\begin{array}{l}\text { Saprolite } \\
\text { (High Liz) }\end{array}$ & $\begin{array}{c}\text { Saprolite (High } \\
\text { Oli/Ens) }\end{array}$ & $\underset{*}{\text { Mixture }}$ \\
\hline 1 & 1 & 0.8 & 0.2 & 0.1 & 0.1 & \\
\hline 2 & 2 & 0.4 & 0.8 & 0.2 & 0.0 & $x$ \\
\hline 2 & 3 & 0.5 & 0.7 & 0.1 & 0.1 & $X$ \\
\hline 1 & 4 & 0.7 & 0.4 & 0.2 & 0.0 & \\
\hline 1 & 5 & 0.8 & 0.3 & 0.1 & 0.1 & \\
\hline 1 & 6 & 0.8 & 0.4 & 0.1 & 0.0 & \\
\hline 1 & 7 & 0.9 & 0.4 & 0.1 & 0.1 & \\
\hline 2 & 8 & 0.6 & 0.7 & 0.1 & 0.0 & $x$ \\
\hline 1 & 9 & 0.7 & 0.1 & 0.3 & 0.1 & \\
\hline 1 & 10 & 0.8 & 0.2 & 0.2 & 0.1 & \\
\hline 2 & 11 & 0.5 & 0.7 & 0.1 & 0.1 & $x$ \\
\hline 1 & 12 & 0.8 & 0.4 & 0.2 & 0.1 & \\
\hline 1 & 13 & 0.7 & 0.2 & 0.1 & 0.1 & \\
\hline 1 & 14 & 0.9 & 0.3 & 0.1 & 0.1 & \\
\hline 1 & 15 & 0.7 & 0.3 & 0.3 & 0.1 & \\
\hline 1 & 16 & 0.8 & 0.4 & 0.1 & 0.0 & \\
\hline 2 & 17 & 0.5 & 0.4 & 0.5 & 0.1 & $X$ \\
\hline 2 & 18 & 0.3 & 0.8 & 0.3 & 0.1 & $X$ \\
\hline 2 & 20 & 0.2 & 0.7 & 0.3 & 0.0 & $x$ \\
\hline 3 & 23 & 0.2 & 0.3 & 0.7 & 0.2 & \\
\hline 2 & 24 & 0.5 & 0.5 & 0.4 & 0.0 & $x$ \\
\hline 3 & 25 & 0.2 & 0.1 & 0.9 & 0.3 & \\
\hline 3 & 26 & 0.1 & 0.3 & 0.8 & 0.2 & \\
\hline 3 & 27 & 0.1 & 0.1 & 0.7 & 0.4 & \\
\hline 3 & 28 & 0.2 & 0.2 & 0.8 & 0.2 & \\
\hline 3 & 29 & 0.1 & 0.4 & 0.7 & 0.1 & \\
\hline 3 & 30 & 0.1 & 0.3 & 0.8 & 0.2 & \\
\hline 3 & 31 & 0.2 & 0.2 & 0.9 & 0.2 & \\
\hline 3 & 32 & 0.2 & 0.1 & 0.9 & 0.3 & \\
\hline 3 & 33 & 0.2 & 0.1 & 0.9 & 0.2 & \\
\hline 4 & 34 & 0.1 & 0.0 & 0.6 & 0.6 & $X$ \\
\hline 3 & 35 & 0.2 & 0.1 & 0.8 & 0.3 & \\
\hline 3 & 36 & 0.2 & 0.2 & 0.8 & 0.4 & \\
\hline 4 & 37 & 0.1 & 0.1 & 0.6 & 0.7 & \\
\hline 4 & 38 & 0.1 & 0.1 & 0.4 & 0.7 & \\
\hline 4 & 39 & 0.1 & 0.1 & 0.4 & 0.8 & \\
\hline 4 & 40 & 0.1 & 0.1 & 0.4 & 0.8 & \\
\hline
\end{tabular}

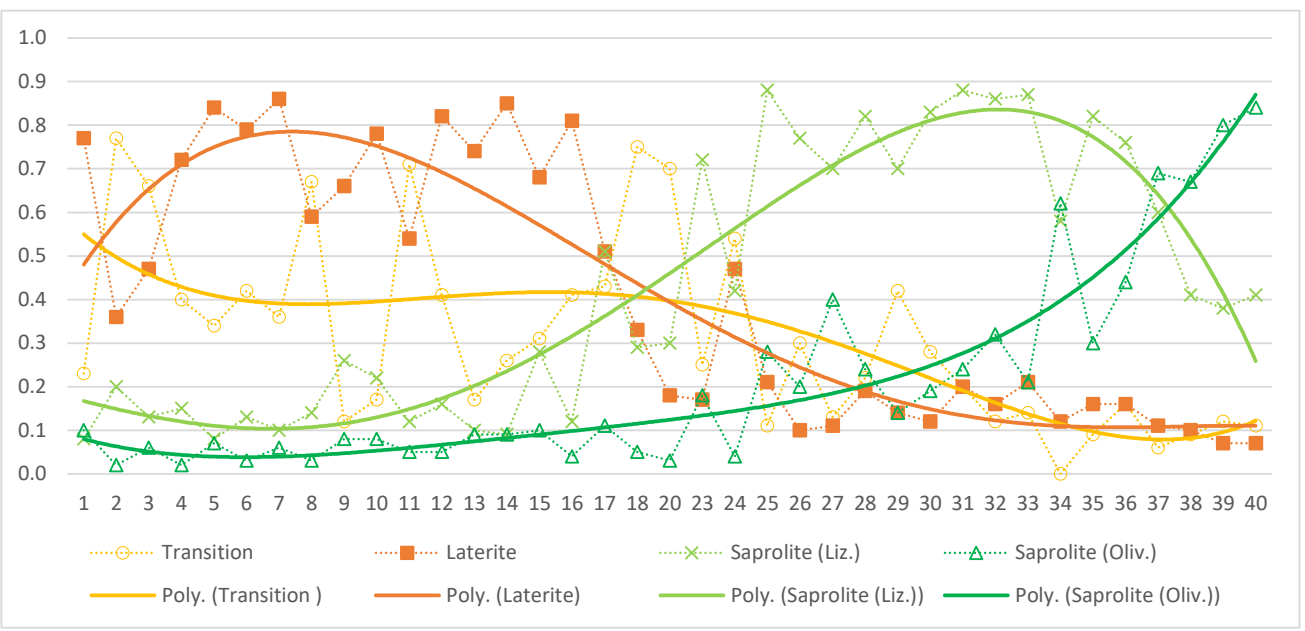

Figure 7. Plot of membership coefficients and trendlines of all clusters against sample number, colors represent the different cluster as identified in Figures 5 and 6 and Table 1.

\subsection{Mineral Identification and Quantification}

Mineral identification of all 40 nickel laterite samples confirmed the presence of two main groups of ores as determined previously using cluster analysis. One group is dominated by oxidic minerals such as goethite, hematite, gibbsite and quartz whereas the second group is characterized by the presence of residual primary Fe/Mg-silicates such as pyroxene and olivine as well as secondary silicates including lizardite and talc. Lizardite peaks appear broad with an FWHM around $0.3^{\circ} 2 \theta$ which indicates lower crystallinity. Such 
poorly ordered hydrous equivalents are commonly referred to as "garnierites" [8,12,13,24,25], named after Jules Garnier who first discovered them in 1864 in New Caledonia [26]. It is a generic name for a green nickel ore that has formed by lateritic weathering of ultramafic rocks (serpentinite, dunite, peridotite). Garnierite is mostly a mixture of various $\mathrm{Ni}$ - and Ni-bearing magnesium layer silicates and occurs in many nickel laterite deposits in the world [27]. Lizardite is the main nickel-bearing mineral in the analyzed samples. A synonym for Ni-Lizardite is "Népouite" [26]. Expandable clay silicates (e.g., smectite with peaks at $\sim 16 \AA$ and $\sim 19 \AA$ ) or (semi)amorphous phases $[28,29]$ were not detected. Structure refinement of the goethite peaks does not show Co-substitution [30-35]. Table 2 summarizes all identified minerals in the investigated nickel laterite samples.

Table 2. Identified minerals in the nickel laterite samples.

\begin{tabular}{llc}
\hline Mineral & Formula & References \\
\hline Goethite & $\mathrm{FeOOH}_{2}$ & {$[27]$} \\
Hematite & $\mathrm{Fe}_{2} \mathrm{O}_{3}$ & {$[36]$} \\
Gibbsite & $\mathrm{Al}(\mathrm{OH})_{3}$ & {$[37]$} \\
Quartz & $\mathrm{SiO}_{2}$ & {$[38]$} \\
Lizardite & $\left(\mathrm{Mg}, \mathrm{Ni}_{3}\left(\mathrm{Si}_{2} \mathrm{O}_{5}\right)(\mathrm{OH})_{4}\right.$ & {$[39]$} \\
Talc & $\mathrm{Mg}_{3}\left[(\mathrm{OH})_{2} \mathrm{Si}_{4} \mathrm{O}_{10}\right]$ & {$[40]$} \\
Enstatite (Pyroxene) & $\mathrm{Mg}_{15.44} \mathrm{Ca}_{0.56} \mathrm{Si}_{16} \mathrm{O}_{48}$ & {$[41]$} \\
Forsterite (Olivine) & $\mathrm{Mg}_{7.17} \mathrm{Fe}_{0.8} \mathrm{Ni}_{0.02} \mathrm{Mn}_{0.01} \mathrm{Si}_{4} \mathrm{O}_{16}$ & {$[42]$} \\
\hline
\end{tabular}

Figure 8 gives an overview of all XRD measurements from the lateritic profile as a surface plot. Different colors indicate the different intensities of the peak of the minerals. The upper laterite horizon of the profile is dominated by the oxide minerals, while in the lower saprolite horizon secondary and primary silicates are the main minerals.

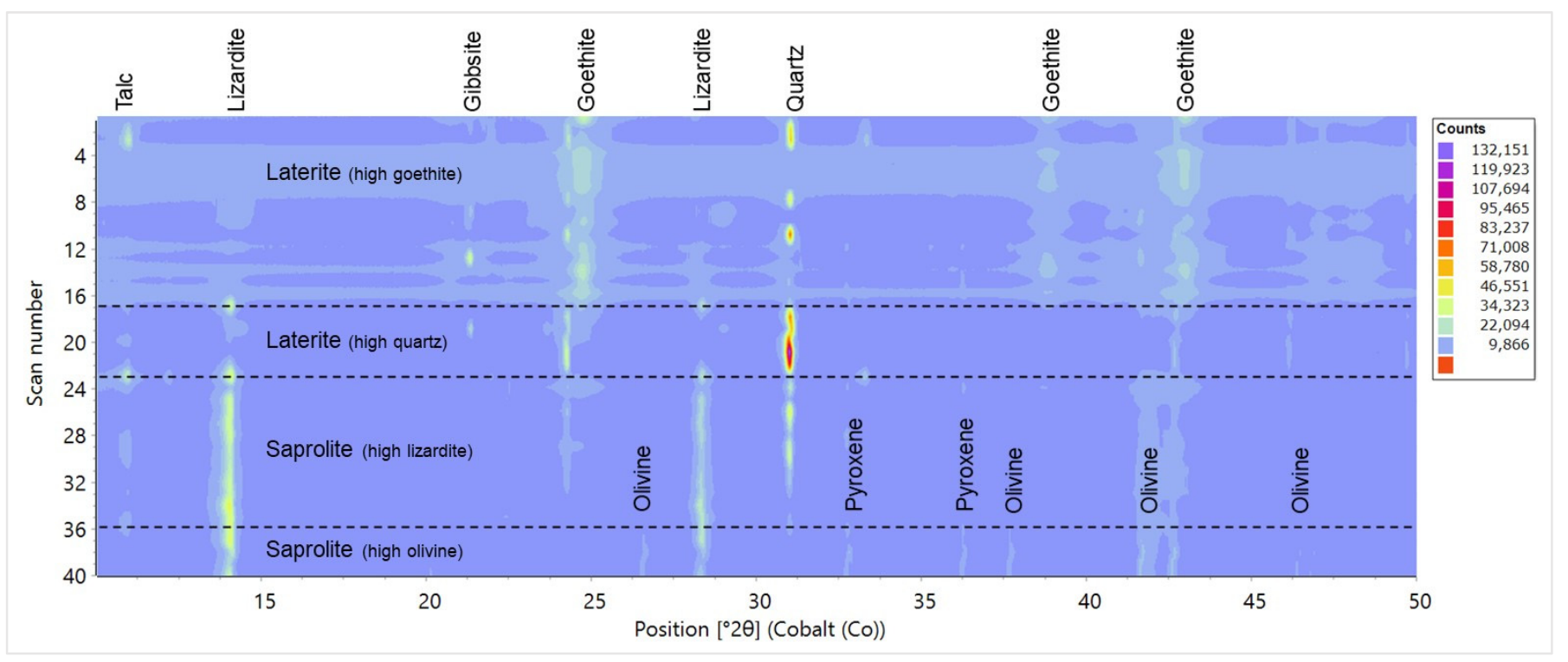

Figure 8. XRD scan surface plot of the region between $10^{\circ} 2 \theta$ and $50^{\circ} 2 \theta$ showing intensities of the main mineral phases.

After mineral identification, the quantitative composition of the samples was determined using the Rietveld method. The Rietveld method is a full-pattern fit method. The measured profile and a profile calculated from crystal structure data are compared. By variation of many parameters, the difference between the two profiles is minimized. Structures and crystallographic data for all phases present in the samples are derived from the COD database, Table 2. 
Since refinement depends on finding the best fit between a calculated and experimental pattern, it is important to have a numerical figure of merit quantifying the quality of the fit and to provide insight into how well the model fits the observed data. For this case study, the $R_{w p}$ (weighted profile R-value) was used [16].

Figure 9 shows an example of the resulting full-pattern Rietveld refinement of one lateritic and one saprolitic ore sample. The mineralogical composition and the $\mathrm{R}_{\mathrm{wp}}$ factors of all samples are summarized in Table 3.

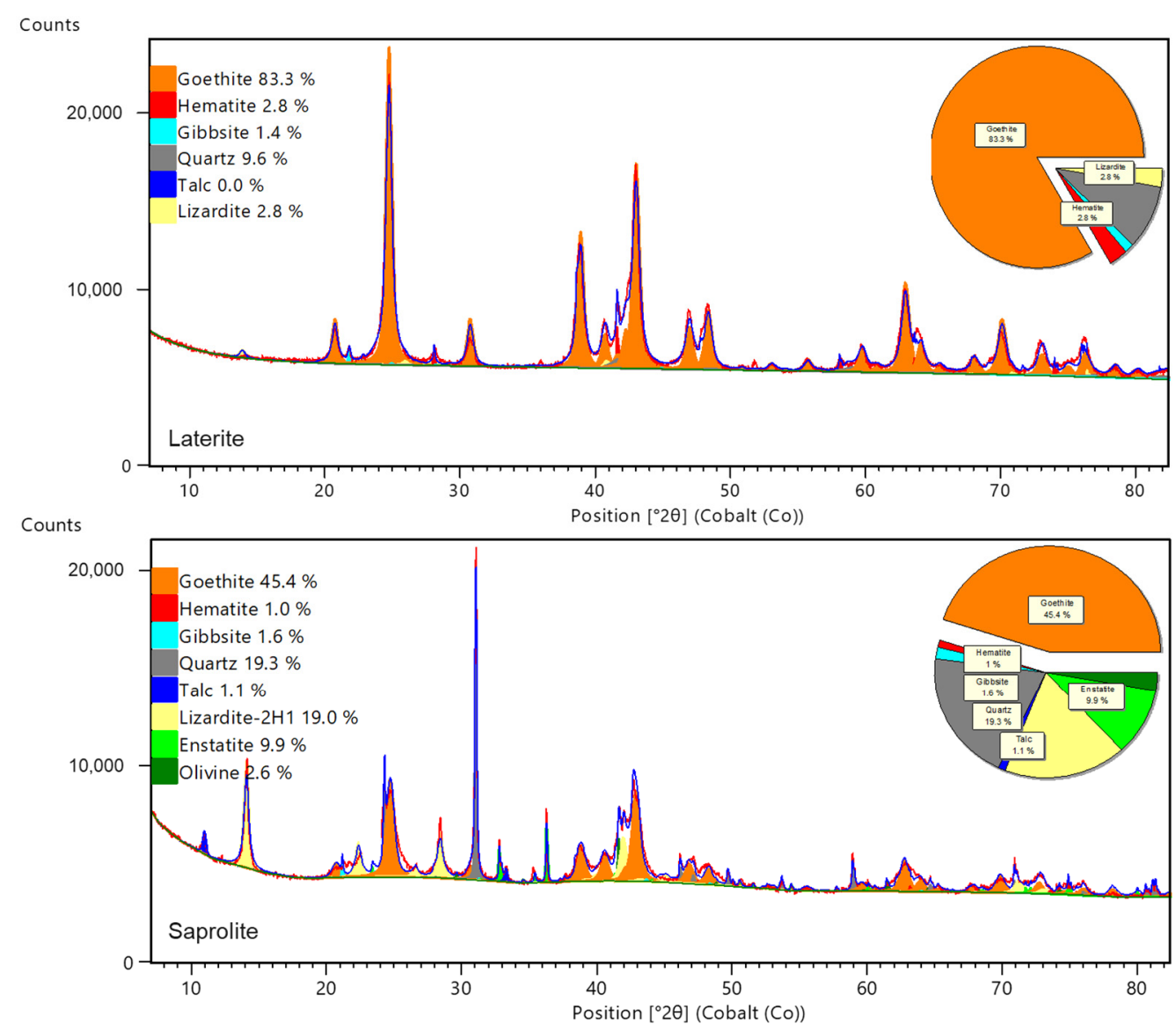

Figure 9. Example of a full-pattern Rietveld quantification of a lateritic $\left(R_{w p}=3.3\right)$ and saprolitic $\left(\mathrm{R}_{\mathrm{wp}}=4.6\right)$ ore.

After generating a model containing all structures of the expected phases, minerals quantification using the Rietveld method can be applied completely automatic without operator interference. It can be used to collect fast feedback for defining grade blocks in the mine, or to sort and blend ores from different mineralogical domains and laterite horizons for a more homogenous ore. This is important because ore mineralogy directly influences downstream processing as described in Section 3.3. and the nickel recovery rates respectively.

To validate the mineralogical composition obtained with the Rietveld method, the theoretical elemental composition was calculated by breaking down mineral phase concentrations into oxide concentrations, and by comparing them with XRF elemental analysis. 
Table 3. Mineral composition determined using the Rietveld method, $\mathrm{R}_{\mathrm{wp}}$ value of the quantification and main elements analyzed with XRF.

\begin{tabular}{|c|c|c|c|c|c|c|c|c|c|c|c|c|c|c|}
\hline$\#$ & $\begin{array}{c}\text { Goe * } \\
{[\%]}\end{array}$ & $\begin{array}{l}\text { Hem } \\
*[\%]\end{array}$ & $\begin{array}{c}\mathrm{Gib} \text { * } \\
{[\%]}\end{array}$ & $\begin{array}{c}\text { Qua * } \\
{[\%]}\end{array}$ & $\begin{array}{l}\text { Tal * } \\
{[\%]}\end{array}$ & $\begin{array}{c}\mathbf{L i z}^{*} \\
{[\%]}\end{array}$ & $\begin{array}{c}\text { Ens * } \\
{[\%]}\end{array}$ & $\begin{array}{l}\text { Oli * } \\
{[\%]}\end{array}$ & $\mathbf{R}_{\mathrm{wp}}$ & $\begin{array}{c}\mathrm{Ni} \\
{[\%]}\end{array}$ & $\begin{array}{c}\text { Co } \\
{[\%]}\end{array}$ & $\begin{array}{c}\mathrm{Fe}_{2} \mathrm{O}_{3} \\
{[\%]}\end{array}$ & $\begin{array}{c}\mathrm{MgO} \\
{[\%]}\end{array}$ & $\begin{array}{c}\mathrm{SiO}_{2} \\
{[\%]}\end{array}$ \\
\hline 1 & 89.4 & 2.1 & 5.6 & 0.7 & 0.0 & 2.2 & 0.0 & 0.0 & 4.6 & 0.6 & 0.0 & 74.7 & 0.7 & 1.2 \\
\hline 2 & 49.0 & 0.7 & 8.2 & 33.2 & 5.3 & 3.6 & 0.0 & 0.0 & 3.5 & 1.6 & 0.1 & 41.1 & 4.2 & 35.8 \\
\hline 3 & 50.4 & 0.8 & 4.5 & 34.3 & 9.2 & 0.9 & 0.0 & 0.0 & 4.6 & 0.7 & 0.1 & 46.1 & 3.6 & 39.3 \\
\hline 4 & 77.4 & 0.7 & 9.1 & 10.2 & 0.5 & 2.1 & 0.0 & 0.0 & 1.9 & 1.6 & 0.6 & 66.3 & 0.9 & 2.6 \\
\hline 5 & 83.6 & 0.3 & 6.7 & 7.5 & 0.2 & 1.7 & 0.0 & 0.0 & 3.1 & 1.2 & 0.2 & 69.9 & 0.7 & 2.1 \\
\hline 6 & 81.6 & 0.7 & 6.3 & 7.7 & 0.8 & 3.0 & 0.0 & 0.0 & 2.4 & 1.9 & 0.3 & 66.5 & 0.9 & 2.8 \\
\hline 7 & 79.2 & 1.7 & 8.3 & 7.5 & 0.3 & 3.0 & 0.0 & 0.0 & 2.7 & 1.7 & 0.4 & 67.2 & 0.8 & 2.3 \\
\hline 8 & 63.8 & 0.3 & 5.4 & 27.7 & 0.2 & 2.7 & 0.0 & 0.0 & 2.5 & 1.2 & 0.2 & 54.4 & 0.8 & 22.2 \\
\hline 9 & 72.5 & 4.0 & 7.5 & 10.4 & 0.1 & 5.6 & 0.0 & 0.0 & 6.6 & 0.7 & 0.0 & 59.8 & 2.9 & 8.9 \\
\hline 10 & 59.5 & 3.1 & 4.9 & 26.0 & 0.1 & 6.3 & 0.0 & 0.0 & 6.9 & 0.9 & 0.0 & 55.5 & 3.3 & 19.0 \\
\hline 11 & 47.6 & 0.4 & 5.6 & 44.5 & 0.2 & 1.6 & 0.0 & 0.0 & 3.2 & 0.9 & 0.1 & 44.4 & 0.8 & 34.2 \\
\hline 12 & 74.2 & 1.7 & 11.5 & 6.4 & 0.3 & 5.8 & 0.0 & 0.0 & 2.9 & 1.4 & 0.1 & 64.2 & 2.6 & 9.8 \\
\hline 13 & 63.9 & 3.4 & 9.5 & 10.9 & 2.6 & 9.7 & 0.0 & 0.0 & 9.6 & 0.8 & 0.0 & 61.7 & 4.8 & 12.7 \\
\hline 14 & 83.3 & 2.8 & 1.4 & 9.6 & 0.0 & 2.8 & 0.0 & 0.0 & 3.3 & 0.3 & 0.0 & 72.0 & 0.7 & 7.1 \\
\hline 15 & 65.7 & 2.9 & 8.9 & 7.2 & 0.6 & 14.7 & 0.0 & 0.0 & 4.7 & 1.1 & 0.0 & 56.5 & 7.1 & 11.4 \\
\hline 16 & 79.8 & 0.5 & 7.6 & 8.2 & 0.7 & 3.2 & 0.0 & 0.0 & 2.3 & 1.5 & 0.2 & 67.1 & 1.4 & 6.6 \\
\hline 17 & 85.3 & 1.3 & 0.1 & 4.4 & 0.6 & 8.3 & 0.0 & 0.0 & 5.5 & 0.8 & 0.1 & 75.3 & 4.6 & 4.5 \\
\hline 18 & 83.8 & 0.9 & 0.1 & 10.4 & 0.7 & 4.0 & 0.0 & 0.0 & 8.9 & 0.9 & 0.0 & 71.8 & 3 & 11.1 \\
\hline 19 & 9.2 & 0.5 & 12.5 & 45.1 & 0.1 & 30.6 & 1.7 & 0.1 & 9.9 & 2.4 & 0.1 & 6.2 & 16.6 & 54.9 \\
\hline 20 & 19.6 & 0.3 & 0.4 & 60.4 & 1.6 & 15.6 & 1.9 & 0.4 & 6.2 & 1.2 & 0.0 & 12.9 & 9.4 & 65 \\
\hline 21 & 5.5 & 0.2 & 0.2 & 86.2 & 0.1 & 4.5 & 2.5 & 0.7 & 6.1 & 0.5 & 0.0 & 3.7 & 5.1 & 83.4 \\
\hline 22 & 7.8 & 0.3 & 0.3 & 69.9 & 1.9 & 19.2 & 0.5 & 0.1 & 8.3 & 0.9 & 0.0 & 4.7 & 14.2 & 67.5 \\
\hline 23 & 28.0 & 1.1 & 1.8 & 5.4 & 25.5 & 32.4 & 1.9 & 3.9 & 9.4 & 2.2 & 0.1 & 21.2 & 23.4 & 37.5 \\
\hline 24 & 45.4 & 1.0 & 1.6 & 19.3 & 1.1 & 19.0 & 9.9 & 2.6 & 4.6 & 1.4 & 0.0 & 37.2 & 15.1 & 34.9 \\
\hline 25 & 37.2 & 0.7 & 1.6 & 5.8 & 0.1 & 40.4 & 9.3 & 5.0 & 7.2 & 2.6 & 0.1 & 27.7 & 24.7 & 37.6 \\
\hline 26 & 18.8 & 0.2 & 0.5 & 42.1 & 0.6 & 25.0 & 6.2 & 6.7 & 8.5 & 1.4 & 0.1 & 14.7 & 15.6 & 62.1 \\
\hline 27 & 25.5 & 0.1 & 1.0 & 21.1 & 0.3 & 39.3 & 6.1 & 6.6 & 8.7 & 2.4 & 0.0 & 17.3 & 20.9 & 49.9 \\
\hline 28 & 24.3 & 0.4 & 0.8 & 13.2 & 0.8 & 26.9 & 24.9 & 8.7 & 8.3 & 1.9 & 0.1 & 17 & 23.4 & 48.8 \\
\hline 29 & 21.2 & 0.5 & 0.8 & 29.2 & 1.9 & 21.6 & 14.7 & 10.2 & 8.5 & 1.6 & 0.0 & 14.8 & 21.2 & 53.6 \\
\hline 30 & 28.4 & 0.8 & 0.9 & 22.2 & 1.8 & 34.1 & 6.9 & 4.9 & 7.1 & 2.6 & 0.1 & 23.9 & 21.0 & 43.7 \\
\hline 31 & 34.9 & 1.0 & 1.5 & 11.0 & 0.6 & 33.4 & 9.2 & 8.4 & 6.9 & 2.5 & 0.1 & 26.4 & 22.7 & 38.1 \\
\hline 32 & 35.9 & 0.7 & 1.1 & 8.9 & 0.5 & 38.1 & 7.3 & 7.4 & 7.8 & 2.4 & 0.1 & 24.5 & 23.2 & 34.1 \\
\hline 33 & 36.5 & 0.8 & 1.3 & 5.5 & 0.7 & 39.9 & 9.3 & 6.1 & 7.1 & 2.3 & 0.1 & 26.8 & 25.3 & 32.5 \\
\hline 34 & 25.8 & 0.4 & 0.2 & 4.4 & 0.0 & 44.7 & 9.4 & 15.0 & 9.7 & 3.3 & 0.0 & 19.5 & 29.7 & 39.7 \\
\hline 35 & 26.7 & 0.3 & 0.5 & 6.9 & 1.8 & 43.8 & 11.2 & 8.7 & 9.8 & 3.2 & 0.0 & 20.2 & 28 & 39.9 \\
\hline 36 & 29.0 & 0.6 & 0.6 & 6.6 & 1.2 & 29.7 & 16.6 & 15.7 & 6.9 & 2.5 & 0.0 & 21.2 & 26.8 & 37.6 \\
\hline 37 & 21.2 & 0.0 & 0.3 & 2.7 & 0.7 & 30.8 & 12.2 & 32.1 & 8.4 & 2.6 & 0.0 & 17.6 & 31.6 & 37.2 \\
\hline 38 & 15.0 & 0.3 & 0.2 & 0.7 & 0.3 & 18.0 & 24.8 & 40.6 & 7.0 & 1.5 & 0.0 & 15.2 & 35.7 & 39.8 \\
\hline 39 & 18.4 & 0.5 & 0.0 & 2.4 & 0.2 & 15.7 & 21.4 & 41.4 & 6.3 & 1.4 & 0.0 & 17.1 & 33.9 & 43.6 \\
\hline 40 & 18.7 & 0.2 & 0.3 & 1.6 & 0.3 & 20.6 & 18.7 & 39.6 & 7.1 & 1.9 & 0.0 & 17.0 & 33.8 & 39.9 \\
\hline
\end{tabular}

* Goe $=$ Goethite, Hem = Hematite, Gib = Gibbsite, Qua = Quartz, Tal = Talc, Liz = Lizardite, Ens = Enstatite, Oli = Olivine.

Figure 10 summarized the mineralogical and elemental composition of all samples within the laterite profile. The results for $\mathrm{Fe}_{2} \mathrm{O}_{3}, \mathrm{MgO}$ and $\mathrm{SiO}_{2}$ show a good agreement. The samples analyzed for this case study represent a typical hydrous $\mathrm{Mg}$-Si-silicate laterite profile based on the mineralogical and elemental composition. The goethite dominated iron crust and red laterite are followed by a transition zone with relatively high amounts of quartz. The saprolite is dominated by the increasing amounts of $\mathrm{Fe} / \mathrm{Mg}$-silicates such as pyroxene and olivine as well as secondary silicates including lizardite and talc. The high amounts of pyroxene and olives in samples $38-40$ indicate proximity to the bedrock of the deposit. 


\section{XRD (mineralogy)}

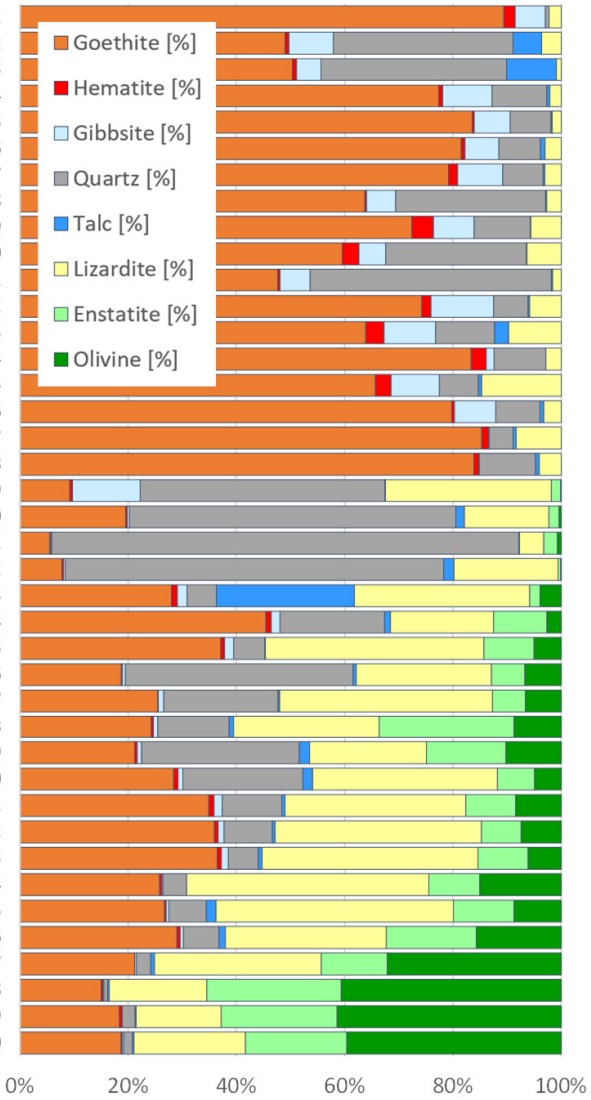

XRD (chemistry calculated) XRF (chemistry)

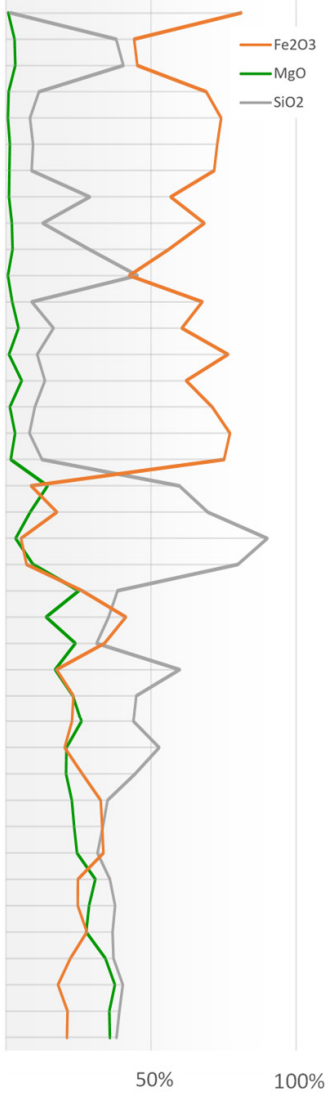

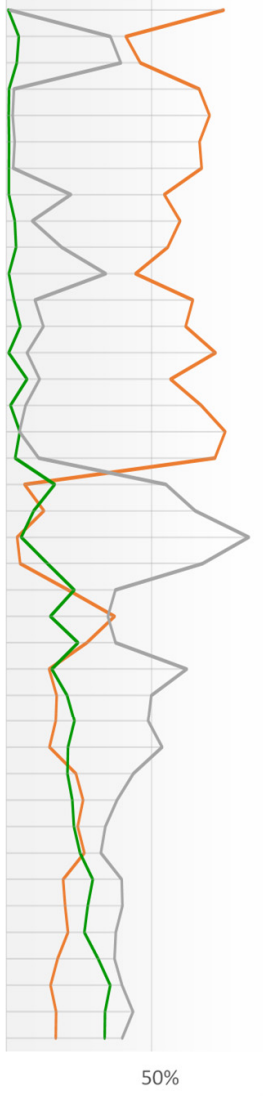

Nickel laterite profile (schematic)

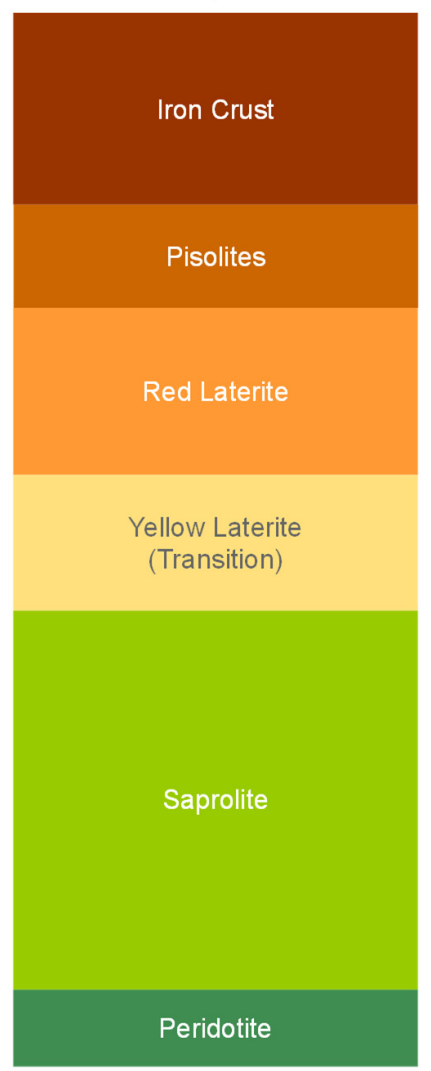

Figure 10. Summary of the mineralogical and elemental composition of 40 samples from a hydrous Mg-Si-silicate laterite profile.

Lizardite is the nickel-bearing mineral in the saprolite and therefore of special economic interest. A comparison of the lizardite and the elemental nickel concentration, Figure 11, shows a good correlation between both values. It proofs that nickel is indeed contained in the mineral lizardite and shows that XRD is beneficial to track not only different ore grades and mineralogical domains but can also give fast feedback about the main nickel mineral and indirectly about the total nickel concentration.

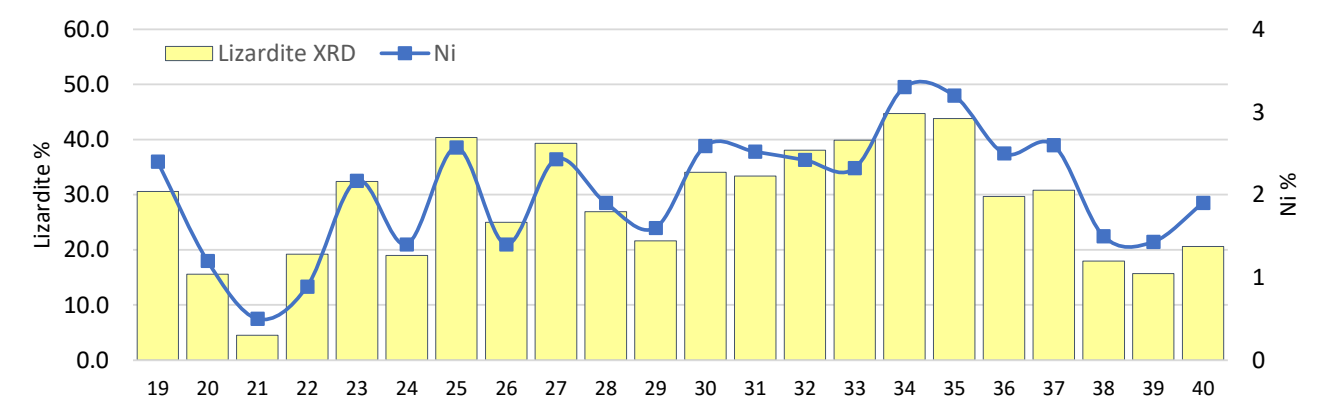

Figure 11. Comparison of the amount of lizardite (XRD) and the nickel content (XRF) in the saprolitic samples of the profile.

\subsection{Mineralogical Monitoring during Pyrometallurgical Processing of Nickel Laterites}

To ensure optimal efficiency for both mining and ore processing, knowledge about the mineralogical composition of the ore feed, but also of the processed materials and products is mandatory. Varying mineralogical composition of the ore blends can affect 
the lifetime of refractories, melting temperature, reducibility and recovery rates during pyrometallurgical processing.

Nickel laterites are suited for pyrometallurgical processing involving drying, calcination/reduction and electric furnace smelting to produce ferronickel or nickel sulfide matte. Figure 12 shows a schematic overview of nickel extraction from laterites by smelting them in an electrical furnace.

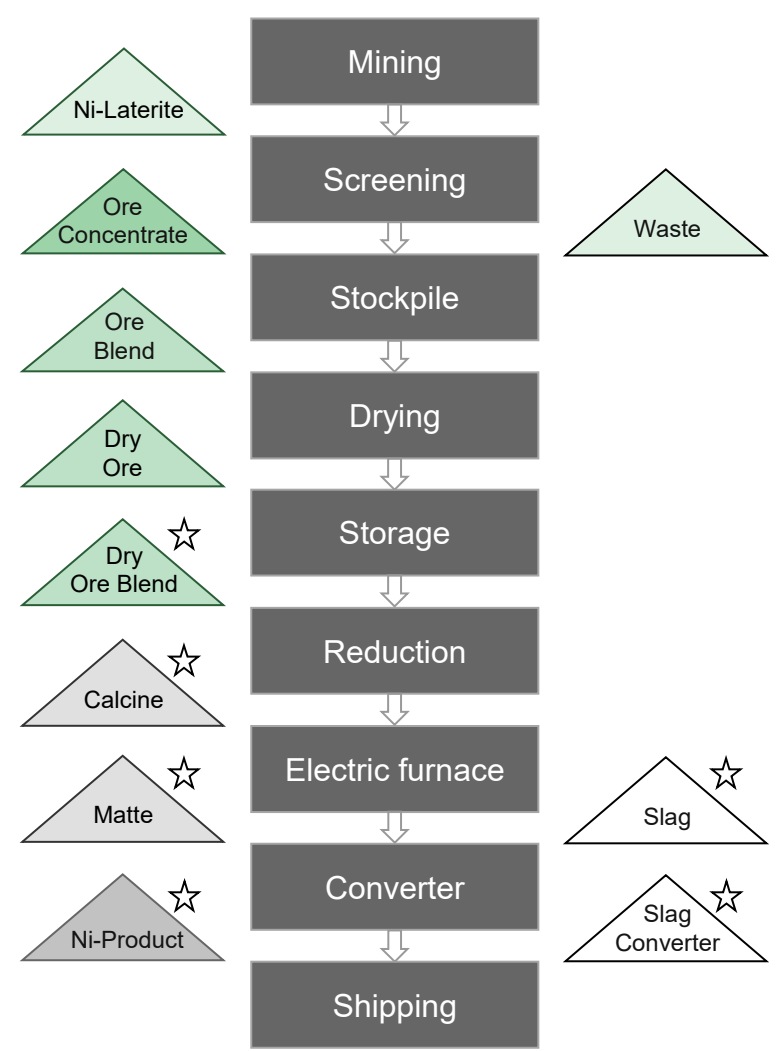

Figure 12. Schematic overview of the pyrometallurgical extraction of nickel from laterites, stars = samples analyzed.

Nickel matte production starts after the ore screening with the drying to reduce the water content from $30-40 \%$ to $20 \%$. The dried nickel ore is further treated in a reduction kiln to remove the final water content. The product of this process is called calcine. Calcine is melted and reduced in an electric arc furnace producing a sulfidic matte and an oxidic slag. The slag is skimmed from the furnace continuously and is disposed of. The matte is tapped periodically as required by the converters. Molten furnace matte is transferred to the converters through ladles. Air/oxygen is blown in to oxidize the remaining iron. Silica flux is added to melt the oxidized iron that is then incorporated into the slag. During converting, the lower grade electric furnace matte is converted to Bessemer matte [43]. The final converter product is granulated, dried, screened and packed for shipment.

It is important to control not only the mineralogical composition of the run-of-mine ore but also the blended feed material, calcine, matte and slag. Samples from six different materials were analyzed for the mineralogical composition. All identified phases are summarized in Table 4. Figure 13 gives an overview of the phase composition investigated with the Rietveld method of the different process streams from the ore blend to the Bessemer matte and slag. 


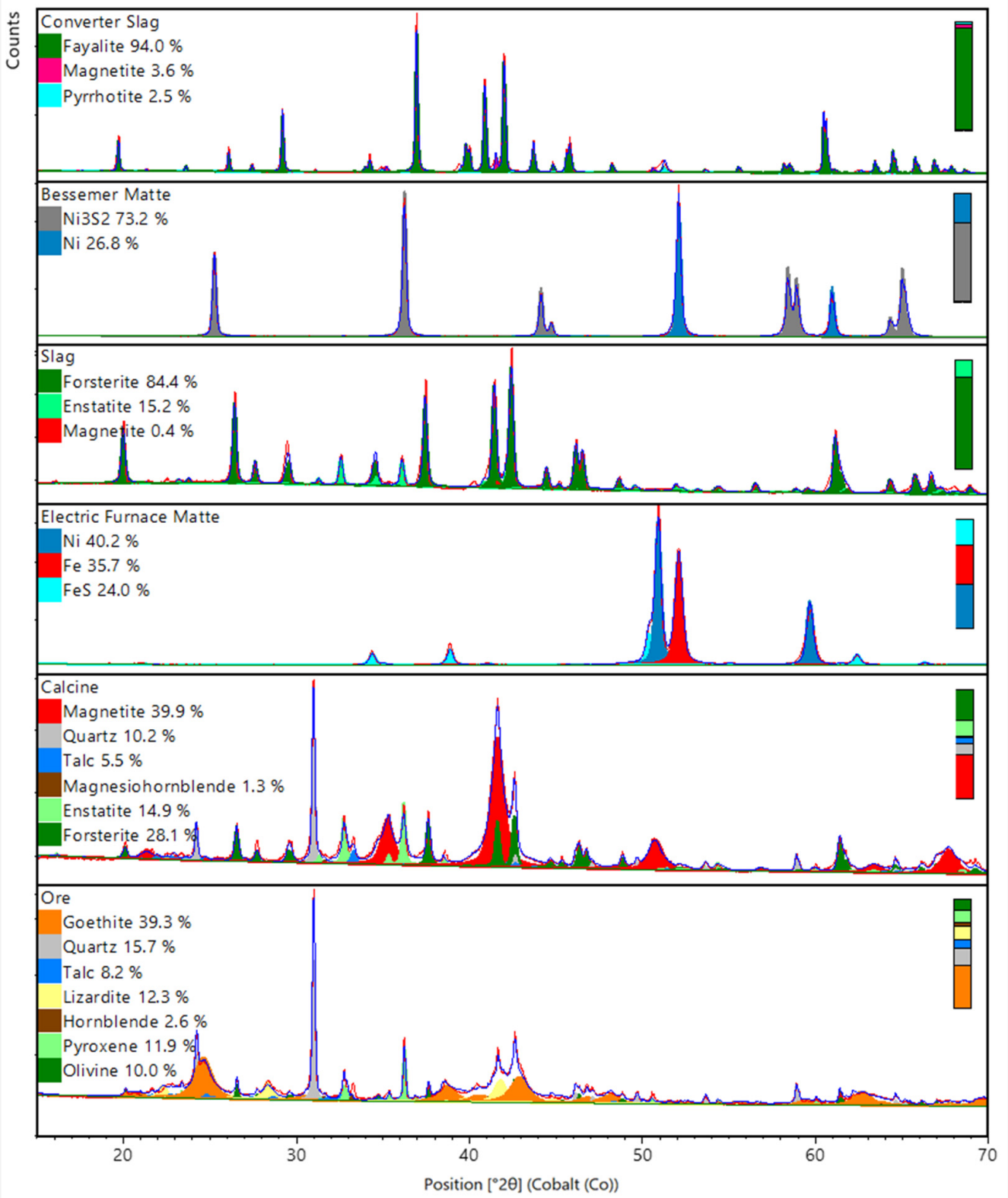

Figure 13. Example of a full-pattern Rietveld quantification for several processed materials of the pyrometallurgical extraction of nickel from laterites (Ore $R_{w p}=4.6$, Calcine $R_{w p}=5.0$, Electric Furnace Matte $R_{w p}=5.5$, Slag $R_{w p}=5.5$, Bessemer Matte $R_{w p}=2.2$, Converter Slag $R_{w p}=6.3$ ).

Table 4. Identified minerals in the process samples.

\begin{tabular}{llc}
\hline Mineral & Formula & References \\
\hline Magnetite & $\mathrm{Fe}_{3} \mathrm{O}_{4}$ & {$[44]$} \\
Hornblende & $(\mathrm{Ca}, \mathrm{Na})_{2-3}(\mathrm{Mg}, \mathrm{Fe}, \mathrm{Al})_{5}(\mathrm{Al}, \mathrm{Si})_{8} \mathrm{O}_{22}(\mathrm{OH}, \mathrm{F})_{2}$ & {$[45]$} \\
Pyrrhotite & $\mathrm{Fe}_{(1-x)} \mathrm{S}$ & {$[46]$} \\
Fayalite (Olivine) & $\mathrm{Fe}_{2} \mathrm{SiO}_{4}$ & {$[47]$} \\
Nickel & $\mathrm{Ni}$ & {$[48]$} \\
Heazlewoodite & $\mathrm{Ni}_{3} \mathrm{~S}_{2}$ & {$[49]$} \\
Iron & $\mathrm{Fe}$ & {$[50]$} \\
Troilite & $\mathrm{FeS}$ & {$[51]$} \\
\hline
\end{tabular}


Lizardite is transformed to forsterite [52] in the calcination. The electric furnace matte consists of $40.2 \%$ nickel metal, $35.7 \%$ iron metal and $24 \%$ iron sulfide (troilite) whereas the corresponding slag consists mainly of silicates (forsterite and enstatite). The final product of the pyrometallurgical processing, Bessemer matte, has a nickel content of about $80 \%$, consisting of $27 \%$ nickel metal and $73 \%$ nickel sulfide. The converter slag is rich in iron silicate and minor amounts of magnetite and pyrrhotite.

The examples demonstrate that frequent and fast mineralogical monitoring during the processing of nickel laterite ores can be a highly valuable tool to stabilize the furnace operation and increase the production of nickel matte despite lower feed grades.

\section{Conclusions}

X-ray diffraction (XRD) can be used as a fast and powerful tool to monitor nickel laterite mining and downstream processing. $\mathrm{XRD}$ is a fast and reliable technique to monitor the mineralogical composition of run-of-mine (RoM) ore, ore blends, calcine, matte and slag.

The mineralogy of the analyzed mine samples represents a typical nickel laterite profile with high amounts of goethite in the lateritic part and Mg-Fe-Silicates in the saprolitic part. The nickel concentration is correlated with the mineral Lizardite. Cluster analysis allows fast sorting of samples in groups of similar mineral composition and can be used as pass/fail analysis tool to sort nickel laterites. It allows objective grade control based on the mineralogical composition. Fuzzy clustering even allows the detection of mixtures of ores from different horizons or mineralogical domains.

Each step of the pyrometallurgical processing can be monitored for the phase composition of products (matte) and waste material (slag). This can lead to increased profitability of a mining operation. Table 5 summarizes the values that mineralogical monitoring using X-ray diffraction can deliver.

Table 5. Value and parameter to increase the profitability of nickel laterite processing.

\begin{tabular}{|c|c|}
\hline Value & Tool \\
\hline Optimization of ore blends from various nickel laterite deposits & Cluster analysis \\
\hline Adjustment of superheat in the feed and optimization of energy costs & Mineralogy of ore blend \\
\hline Control of mineralization acidity & Silicate composition \\
\hline Prevention of highly corrosive slag causing erosion of the refractories & Silicate composition \\
\hline Better reducibility in the furnace & Olivine content \\
\hline Boost nickel recovery rates and reduction of metal loss in slag & Slag composition \\
\hline Increase of cobalt recoveries. & Co-bearing minerals \\
\hline
\end{tabular}

Today's optics, detectors, and software for XRD analysis can provide rapid $(<5 \mathrm{~min})$ and accurate analyses, suitable for process control environments as well as research even with a small benchtop diffractometer. All evaluation methods such as cluster analysis, phase identification and quantification can run simultaneously and allow fast counteraction on changing conditions in the plant or in the mine. The complete analysis is ready for automation and can be easily included in existing automation lines.

Funding: This research received no external funding.

Data Availability Statement: All data were gathered and treated at Malvern Panalytical B.V laboratories in Almelo (The Netherlands).

Conflicts of Interest: The author declares no conflict of interest.

\section{References}

1. Butt, C.R.M.; Cluzel, D. Nickel Laterite Ore Deposits: Weathered Serpentinites. Elements 2013, 9, 123-128. [CrossRef]

2. Garvin, M.M.; Simon, M.J. A detailed assessment of global nickel resource trends and endowments. Soc. Econ. Geol. Inc. Econ. Geol. 2014, 109, 1813-1814.

3. DERA. Batterierohstoffe für Die Elektromobilität; DERA Themenheft: Berlin, Germany, 2021; p. 26. 
4. Meshram, P.; Pandey, B.D. Advanced review on extraction of nickel from primary and secondary sources. Miner. Process. Extr. Metall. Rev. 2019, 40, 157-193. [CrossRef]

5. Agatzini-Leonardou, S.; Tsakiridis, P.E.; Oustadakis, P.; Karidakis, T.; Katsiapi, A. Hydrometallurgical process for the separation and recovery of nickel from sulphate heap leach liquor of nickelliferrous laterite ores. Miner. Eng. 2009, 22, 1181-1192. [CrossRef]

6. Tian, H.; Pan, J.; Zhu, D.; Yang, C.; Guo, Z.; Xue, Y. Imporved beneficiation of nickel and iron from a low-grade saprolite laterite by addition of limonitic laterite ore and $\mathrm{CaCO}_{3}$. J. Mater. Res. Technol. 2020, 9, 2578-2589. [CrossRef]

7. Lv, X.W.; Bai, C.G.; He, S.P.; Huang, Q.Y. Mineral change of Philippine and Indonesian nickel laterite ore during sintering and mineralogy of the sinter. ISIJ Int. 2010, 50, 380-385. [CrossRef]

8. Brand, N.W.; Butt, C.R.M.; Elias, M. Nickel laterites: Classification and features. AGSO J. Aust. Geol. Geophys. 1998, 17, 81-88.

9. Maurizot, P.; Sevin, B.; Iseppi, M.; Giband, T. Nickel-Bearing Laterite Deposits in Accretionary Context and the Case of New Caledonia: From the Large-Scale Structure of Earth to Our Everyday Appliances. GSA Today 2019, 29, 4-10. [CrossRef]

10. Brindley, G.W.; Hang, P.T. The nature of garnierites-I. Structures, Chemical Composition and Color Characteristic. Clays Clay Miner. 1973, 21, 27-40. [CrossRef]

11. Brindley, G.W.; Maksimovic, Z. The nature and nomenclature of hydrous nickel-containing silicates. Clay Miner. 1974, 10, 271-277. [CrossRef]

12. Wells, M.A.; Ramanaidou, E.R.; Verrall, M.; Tessarolo, C. Mineralogy and crystal chemistry of "garnierites" in the Goro lateritic nickel deposit, New Caledonia. Eur. J. Miner. 2009, 21, 467-483. [CrossRef]

13. Horn, R.A.; Bacon, W.G. Goro Nickel-Cobalt Project Located in French Overseas Territorial Community (Collectivite Territoriale) of New Caledonia; Goro Nickel Technical Report; Goro Nickel: Noumea, New Caledonia, 2002; p. 116.

14. Degen, T.; Sadki, M.; Bron, E.; König, U.; Nénert, G. The HighScore suite. Powder Diffr. 2014, 29, S13-S18. [CrossRef]

15. COD Crystallography Open Database. Available online: http://www.crystallography.net/cod/ (accessed on 24 October 2021).

16. Rietveld, H.M. A profile refinement method for nuclear and magnetic structures. J. Appl. Crystallogr. 1969, 2, 65-71. [CrossRef]

17. Rietveld, H.M. Line profiles of neutron powder-diffraction peaks for structure refinement. Acta Crystallogr. 1967, 22, 151-152. [CrossRef]

18. Young, R.A. The Rietveld Method. International Union of Crystallography; Oxford University Press: Oxford, UK, 1993 ; p. 298.

19. Kelley, L.A.; Gardner, S.P.; Sutcliffe, M.J. An automated approach for clustering an ensemble of NMR-derived protein structures into conformationally related subfamilies. Protein Eng. Des. Sel. 1996, 9, 1063-1065. [CrossRef] [PubMed]

20. Liao, B.; Chen, J. The application of cluster analysis in X-ray diffraction phase analysis. J. Appl. Crystallogr. 1992, $25,336-339$. [CrossRef]

21. Van der Maaten, L.J.P.; Hinton, G.E. Visualizing High-Dimensional Data Using t-SNE. J. Mach. Learn. Res. 2008, 9, $2579-2605$.

22. Sato, M.; Sato, Y.; Jain, L.C. Fuzzy Clustering Models and Applications, Studies in Fuzziness and Soft Computing; Springer: NewYork, NY, USA, 1997; Volume 9, p. 122.

23. Everitt, B.S.; Landau, S.; Leese, M. Cluster Analysis, 5th ed.; Wiley: London, UK, 2011; 346p.

24. Garnier, J. Essai sur la geologie et les ressources minerales de la Nouvelle-Caledonie. Ann. Des Mines 1867, 6, 1-92.

25. Faust, G.T. The hydrous nickel-magnesium silicgroup-The garnierite group. Am. Min. 1966, 51, $279-298$.

26. Glasser, M.E. Note sur une espèce minérale nouvelle, la népouite, silicate hydraté de nickel et de magnésie. Bull. De La Société Française De Minéralogie 1907, 30, 17-28. [CrossRef]

27. Brindley, G.W.; Wan, H.M. Composition, structures, and thermal behavior of nickel-containing minerals in the lizardite-nepouite series. Am. Mineral. 1975, 60, 863-871.

28. Gamaletsos, P.N.; Kalatha, S.; Godelitsas, A.; Economou-Eliopoulos, M.; Göttlicher, J.; Steininger, R. Arsenic distribution and speciation in the bauxitic Fe-Ni-laterite ore deposit of the Patitira mine, Lokris area (Greece). J. Geochem. Explor. 2018, 194, 189-197. [CrossRef]

29. Samouhos, M.; Godelitsas, A.; Nomikou, C.; Taxiarchou, M.; Tsakiridis, P.; Zavasnik, J.; Gamaletsos, P.N.; Apostolikas, A. New insights into nanomineralogy and geochemistry of Ni-laterite ores from central Greece (Larymna and Evia depositis). Geochemistry 2018, 12, 5 .

30. Alvarez, M.; Sileo, E.E.; Rueda, E.H. Structure and reactivity of synthetic Co-substituted goethites. Am. Miner. 2008, 93, 584-590. [CrossRef]

31. Gasser, U.G.; Jeanroy, E.; Mustin, C.; Barres, O.; Nüesch, R.; Berthelin, J.; Herbillon, A.J. Properties of synthetic goethites with Co for Fe substitution. Clay Miner. 1996, 31, 465-476. [CrossRef]

32. Cornell, R.M.; Schwertmann, U. The Iron Oxides; VHC Verlagsgesellschaft: Weinheim, Germany, 1996 ; pp. 35-47.

33. Cornell, R.M.; Giovanoli, R. Effect of cobalt on the formation of crystalline iron oxides from ferrihydrite in alkaline media. Clays Clay Min. 1989, 37, 65-70. [CrossRef]

34. Cornell, R.M. Simultaneous incooperation od Mn, Ni, Co in the goethite ( $\alpha$-FeOOH) structure. Clay Miner. 1991, 2, 427-430. [CrossRef]

35. Pozas, R.; Rojas, T.C.; Ocaña, M.; Serna, C.J. The Nature of Co in Synthetic Co-substituted Goethites. Clays Clay Miner. 2004, 52, 760-766. [CrossRef]

36. Blake, R.L.; Hessevick, R.E.; Zoltai, T.; Finger, L.W. Refinement of the hematite structure. Am. Min. 1966, 51, 123-129.

37. Saalfeld, H.; Wedde, M. Refinement of the crystal structure of gibbsite, $\mathrm{Al}(\mathrm{OH})_{3}$. Z. Für Krist. 1974, 139, 129-135. [CrossRef]

38. Gualtieri, A. Accuracy of XRPD QPA using the combined Rietveld-RIR method. J. Appl. Crystallogr. 2000, 33, 267-278. [CrossRef] 
39. Guggenheim, S.; Zhan, W. Effect of temperature on the structures of lizardite-1T and lizardite-2H1. Can. Min. 1998, 36, 1587-1594.

40. Perdikatsis, B.; Burzlaff, H. Strukturverfeinerung am Talk $\mathrm{Mg}_{3}\left[(\mathrm{OH})_{2} \mathrm{Si}_{4} \mathrm{O}_{10}\right]$. Z. Für Krist. Cryst. Mater. 1981, 156, 177-186. [CrossRef]

41. Nestola, F.; Gatta, G.D.; Ballaran, T.B. The effect of Ca substitution on the elastic and structural behavior of orthoenstatite. Am. Miner. 2006, 91, 809-815. [CrossRef]

42. Ottonello, G.; Princivalle, F.; Della Giusta, A. Temperature, composition, and $\mathrm{fO}_{2}$ effects on intersite distribution of $\mathrm{Mg}_{\text {and }} \mathrm{Fe}^{2+}$ in olivines. Phys. Chem. Miner. 1990, 17, 301-312. [CrossRef]

43. Bessemer, H. Sir Henry Bessemer, F.R.S. An Autobiography; Offices of “Engineering": London, UK, $1905 ;$ p. 176.

44. Nakagiri, N.; Manghnani, M.H.; Ming, L.C.; Kimura, S. Crystal structure of magnetite under pressure. Phys. Chem. Miner. 1986, 13, 238-244. [CrossRef]

45. Mancini, F.; Sillanpaa, R.; Marshall, B.; Papunen, H. Magnesian hornblende from a metamorphosed ultramafic body in southwestern Finland: Crystal chemistry and petrological implications. Can. Mineral. 1996, 34, 835-844.

46. Elliot, A.D. Structure of pyrrhotite $5 \mathrm{C}\left(\mathrm{Fe}_{9} \mathrm{~S}_{10}\right)$. Acta Crystallogr. Sect. B Struct. Sci. 2010, 66, 271-279. [CrossRef]

47. Lottermoser, W.; Steiner, K.; Grodzicki, M.; Jiang, K.; Scharfetter, G.; Bats, J.W.; Redhammer, G.; Treutmann, W.; Hosoya, S.; Amthauer, G. The electric field gradient in synthetic fayalite $\alpha-\mathrm{Fe}_{2} \mathrm{SiO}_{4}$ at moderate temperatures. Phys. Chem. Miner. 2002, 29, 112-121. [CrossRef]

48. Leineweber, A.; Jacobs, H.; Hull, S. Ordering of Nitrogen in Nickel Nitride $\mathrm{Ni}_{3} \mathrm{~N}$ Determined by Neutron Diffraction. Inorg. Chem. 2001, 40, 5818-5822. [CrossRef]

49. Fleet, M.E. The crystal structure of heazlewoodite, and metallic bonds in sulfide minerals. Am. Min. 1977, 62, 341-345.

50. Woodward, P.M.; Suard, E.; Karen, P. Structural Tuning of Charge, Orbital, and Spin Ordering in Double-Cell Perovskite Series between $\mathrm{NdBaFe}_{2} \mathrm{O}_{5}$ and $\mathrm{HoBaFe}_{2} \mathrm{O}_{5}$. J. Am. Chem. Soc. 2003, 125, 8889-8899. [CrossRef] [PubMed]

51. Bertaut, F. La structure de sulfure de fer. J. De Phys. Et Du Radium 1954, 15, 775.

52. Setiawan, I.; Febrina, E.; Subagja, R.; Harjanto, S.; Firdiyono, F. Investigations on mineralogical characteristics of Indonesian nickel laterite ores during the roasting process. IOP Conf. Ser. Mater. Sci. Eng. 2019, 541, 012038. [CrossRef] 